\title{
High performance work systems and corporate performance: the influence of entrepreneurial orientation and organizational learning
}

\author{
Chunling Zhu' ${ }^{1 *}$, Anqi Liu' and Guoling Chen ${ }^{2}$
}

\footnotetext{
*Correspondence: zhuchunling@ rbs.ruc.edu.cn

${ }^{1}$ Renmin University of China, Beijing 100872, China

Full list of author information is available at the end of the article
}

\begin{abstract}
This study investigates the functioning mechanisms of how high performance work systems (HPWS) affect organizational performance. We propose that (HPWS) can positively affect organizational performance through the mediating role of entrepreneurial orientation. An organization with high performance work systems can perform better if it enjoys high level of organizational learning. We design and administer a survey questionnaire to high-level executives or founders of companies from manufacturing and service industries and receive 176 valid responses. The results of the empirical data indicate that the relationship between high performance work systems and corporate performance is more positive when organizational learning is stronger. Entrepreneurial orientation partially mediates the relationship between high performance work systems and organizational performance. This study opens new research avenues by extending and incorporating explanations and predictions of HPWS and entrepreneurial orientation, two areas that largely have been considered independently of each other. Implications for practice and directions for future research are provided.

Keywords: High performance work systems, Entrepreneurial orientation, Organizational learning, Corporate performance
\end{abstract}

\section{Introduction}

Considering employees as a key source of competitive advantage, strategic human resource management is gaining increasing importance in knowledge-based economies and rapidly changing environments (Prieto and Santana 2012; Sun et al. 2007). As valuable, rare and inimitable assets for organizations because of their firm-specific, socially complex and path-dependent characteristics, human resource practices help firms obtain sustainable competitive advantages (Collins and Clark 2003). Among the broad concepts of strategic human resources, high performance work systems stand out as reflecting the basic philosophy and practices of strategic human resource management and shape the attitudes, skills and behaviors of staff by discovering and utilizing knowledge, thereby achieving organizational goals (Chen 2009; Collins and Clark 2003).

High performance work systems (HPWS) have been extensively discussed despite their brief history. As there is no agreement on the definition of this concept, it can

(c) The Author(s). 2018 Open Access This article is distributed under the terms of the Creative Commons Attribution 4.0 International License (http://creativecommons.org/licenses/by/4.0/), which permits unrestricted use, distribution, and reproduction in any medium, provided you give appropriate credit to the original author(s) and the source, provide a link to the Creative Commons license, and indicate if changes were made. 
generally be regarded as an organic combination of a series of coordinating and cooperating human resource management practices in order to enhance individual and organizational performance (Snell and Bohlander 2010). By breaking the traditional hierarchical management model, HPWS use flat organizational structures to provide staff with wide-ranging training, safe environments, management and competitive compensation, organizational identification and productivity, which lead to sustainable competitive advantages and long-term individual and organizational development (Pak and Kim 2016).

Research on HPWS includes both organizational level and individual level studies. At the organizational level, scholars have verified the causal relationship between HPWS and corporate performance (Becker and Huselid 2006; Shin and Konrad 2017). At the individual level, empirical studies suggest HPWS can improve personal performance such as job satisfaction, service quality, organizational citizenship behavior and information sharing (Cheng and Wang 2011; Sun et al. 2007). However, the extant literature on the intermediate linkage between HPWS and performance has yielded only limited insights into the influence of the use of HPWS on performance at the organizational level (e.g., Lee and Bang 2012). As argued by Laursen and Foss (2003), the understanding of the relationship between HPWS and corporate performance needs to be extended. What is missing from the resource-based view is looking inside the process to explore how and why HPWS enhance corporate performance (Way and Johnson 2005; Wei and Lau 2010).

Given the essential role of HPWS in performance, it is especially important to examine specific pathways through which this effect occurs. It is assumed that the implementation of HPWS can improve the level of innovation and organizational commitment, and therefore promote entrepreneurial orientation (Gittell et al. 2009; Herrmann and Felfe 2014). With innovation, risk-taking and proactiveness, companies are more inclined to expand markets, launch new products and make decisions ahead of competitors, thus improving corporate performance (Hunt and Arnett 2006; Messersmith and Wales 2013). Therefore, the extant literature suggests that entrepreneurial orientation can be a bridge between HPWS and corporate performance. However, although scholars in the field of entrepreneurship agree that human resource management practices are antecedents to entrepreneurial orientation (De Kok and Den Hartog 2006; Schuler 1986), the consensus is largely based on conceptual work which lacks comprehensive empirical tests (Schmelter et al. 2010). In the few existing empirical analyses, there are conflicting results. Despite positive results between entrepreneurial orientation and corporate performance (Gupta and Batra 2016; Rauch et al. 2009; Thanos et al. 2016), some empirical research has found no significant relationship or inverted U-shaped relation between them (Messersmith and Wales 2013; Tang et al. 2008; Wales et al. 2013). These confusing results require deeper and more holistic perspectives of the function of entrepreneurial orientation.

Furthermore, successful implementation of HPWS is restricted by the absorptive ability of the organization. Specifically, the absorptive ability takes the form of organizational learning, through which an organization captures, transfers and shares knowledge to improve its operation and optimizes the organizational structure in order to achieve long-term development (Hassan and Alhakim 2011; Sanzo et al. 2012). Through organizational learning, employees can gain knowledge, strategize creative 
ideas and improve job autonomy. However, companies cannot easily spread knowledge among staff to achieve organizational goals as knowledge is embedded in human capital. High levels of organizational learning may be needed to ensure the effective implementation of HPWS. Corporations with higher levels of organizational learning can more effectively put high performance work systems into effect and bring their positive effects on corporate performance into full play (Fu et al. 2015). Consequently, organizational learning may influence the relationship between HPWS and corporate performance.

This study aims to explore the functioning mechanism of entrepreneurial orientation and organizational learning in the HPWS-performance link. It is believed that corporate performance provides feedback on HPWS in the form of information and this feedback generates both the data and the slack resources needed to support the adaptive process of HPWS implementation (Shin and Konrad 2017). In line with the resourcebased view (Barney 1991) and organizational learning literature, we propose that organizational learning can be the moderator in the link between HPWS and corporate performance. When organizational learning is stronger, this link can be more positive. Entrepreneurial orientation positively mediates this relationship. The theoretical model is illustrated in Fig. 1.

By proposing this theoretical framework, this study contributes to literature development in several aspects. First, it further explores the mediating and moderating mechanisms between HPWS and corporate performance. To break the limitation of the "black box", this study employs mature scales to test relevant constructs. Second, we innovatively introduce entrepreneurial orientation as the mediator in the model, attempting to further reveal the relationship among HPWS, entrepreneurial orientation and corporate performance and expand the concept of entrepreneurship to some extent. Third, it enriches the study of organizational learning by investigating its moderating role in the HPWS and corporate performance link.

In the following parts, we develop hypotheses through briefly reviewing the literature on HPWS, entrepreneurial orientation and organizational learning. Then, the methodology for the study is introduced. We empirically analyze the data and draw conclusions. Implications and limitations are discussed in the last section.

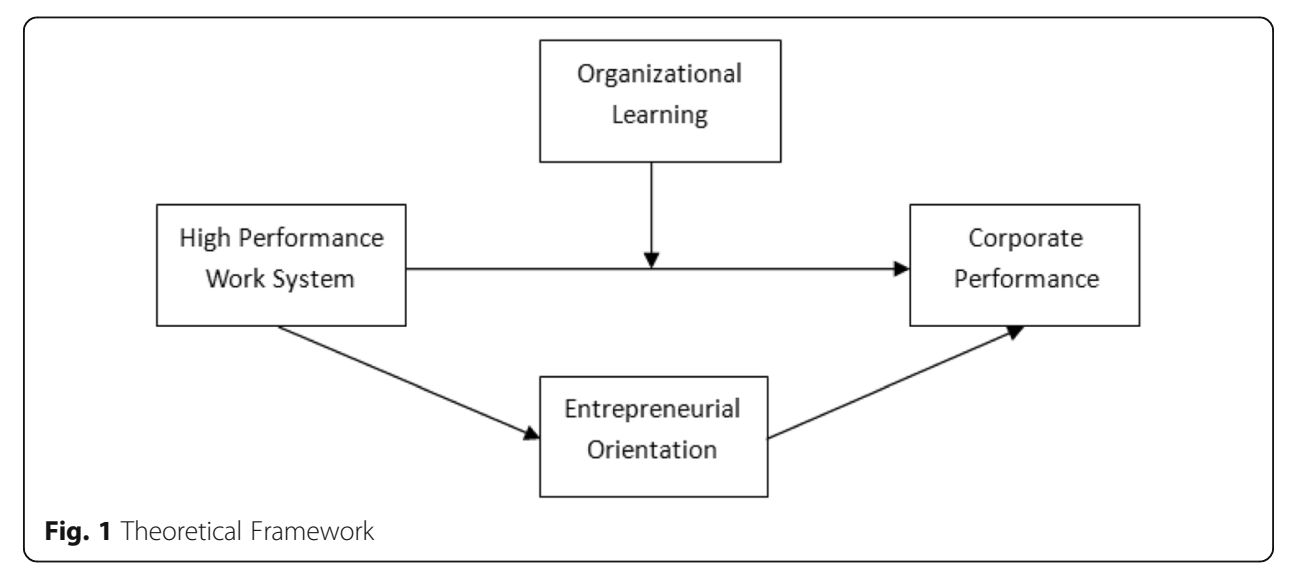




\section{Literature review and hypotheses development}

\section{High performance work systems}

The concept of HPWS, also called high involvement work systems, best human resource management practices and high commitment work systems, was first described by Huselid (1995). However, as a relatively new concept, the definition of high performance work systems has not yet reached a consensus among scholars (Takeuchi et al. 2007). Generally speaking, HPWS refers to a set of HR practices aimed at enhancing staff skills, commitment and productivity, thereby transferring human capital into a source of sustainable competitive advantage (Pak and Kim 2016).

Key dimensions of HPWS include selective hiring procedures, employment security, decentralization of decision making, extensive training, information sharing, and fair payment (Pfeffer 1998). Each dimension of human resource practices is closely related and mutually coordinated. A set of research studies has tested the respective influence of each dimension (Schmelter et al. 2010). However, a meta-analysis of Chinese firms suggests HPWS, rather than a single human resource management practice, has a significantly positive influence on corporate performance, and an even stronger influence on non-financial performance (Zhang et al. 2012).

From different perspectives, researchers have explored the significance of HPWS. More specifically, there are at least three streams of research on HPWS. From the strategic development perspective, the first stream emphasizes the match of HPWS and corporate strategy, focusing on its consistency with the outside factors. As Huselid (1995) said, HPWS originates from and serves corporate strategy. The match between HPWS and corporate strategy and among different human resource management practices are highly valued. The second stream regards HPWS as systems that include a series of coordinated and compatible human resource management practices, emphasizing the accordance of internal issues (Datta and Wright 2005; Pfeffer 1996). From a systematic perspective, HPWS is one of the sources from which firms can obtain sustainable competitive advantages. The third one suggests that effective implementation of HPWS requires the participation of employees (Edwards and Wright 2001; Guthrie 2001). Different from the general employer-employee relationship, HPWS is helpful to establish a community of employee participation, commitment and authorization at the individual level. We consider HPWS to be an organic system which consists of related human resource management practices, including strict recruiting procedures, broad training processes, information sharing, work design, inside promotion channels, employee authorization and performance-based payment. Through the implementation of HPWS, the probability of employee participation is improved, thus high-quality human capital is sustained.

Over the past two decades, studies on HPWS have come under pressure to illustrate their contribution to organizational performance (Batt and Colvin 2011; Hayton 2005; Messersmith and Guthrie 2010). At the organizational level, HPWS is considered to break the traditional hierarchical management mode and establish a flat organizational structure. The managerial practices provide employees with safe working environments, offer broad training projects and opportunities to participate in decision-making, competitive payment and transparent communication channels. From the perspective of the resource-based view, when different human resource management practices are integrated into a synergic system and embedded in an organization, the system will be 
heterogeneous, socially complicated and inimitable. Therefore, the system can contribute to organizational performance such as firm productivity and innovativeness, thereby helping the organization obtain sustained competitive advantages and enhance performance (Becker and Huselid 2006).

On the other hand, HPWS are also considered as tools to control the attitudes and behaviors of employees through providing supportive working environments at the individual level (Links et al. 2013; Shi and Li 2011). Employees are considered the key carrier of HPWS (Zhu and Chen 2014). On the basis of the social exchange literature, HPWS can formulate an exchange relationship between an organization and employees and bring more return for the organization (Xiao and Björkman 2006). Through skill training, career planning and knowledge improvement, employees can feel the support of their organization and a strong sense of identity with their position. Consequently, HPWS enhances organizational commitment and relationships among employees, and subsequently influences the attitude and behavior of employees (Gittell et al. 2009). In return, employees provide positive feedback and supportive social behaviors to the organization (Bashir et al. 2012; Khazanchi and Masterson 2011). Therefore, with investment in employees in the long term, HPWS improves the level of organizational commitment, thereby enhancing the improvement of the organization (Ehrnrooth and Björkman 2012; Kinnie et al. 2000).

Prior studies have illustrated the positive relationships between HPWS and corporate performance. Therefore, scholars have called for researchers to dive deeper to reveal the effect mechanism of HPWS on corporate performance (Way and Johnson 2005; Wei and Lau 2010).

\section{High performance work systems and entrepreneurial orientation}

The concept of entrepreneurial orientation originates from the strategy decision mode set out by Miles et al. (1978). Entrepreneurial orientation can be viewed as a mind pattern of an organization that reflects entrepreneurial attitudes and willingness when starting new businesses (Covin and Slevin 1989; Hu and Zhang 2011). It is a key element of organizational culture and can be reflected in activities such as daily operations and in decision-making processes.

Miller and Friesen (1982) first proposed that entrepreneurial orientation contained three dimensions, namely innovativeness, proactiveness and risk-taking. Innovativeness refers to the tendency to search for novel and new ideas to solve challenges (Morris et al. 2002). Risk-taking is defined as entering into a costly commitment with uncertain outcomes (Pearce et al. 2010). Proactiveness refers to the exploitation of first-mover advantages and anticipation of future events (Lumpkin and Dess 1996). The threedimensional approach has gradually been accepted by most researchers in this field.

Whether an organization has an entrepreneurial orientation or not rests in the entrepreneurial spirit of its employees. Therefore, it is especially important for companies to encourage employees to build entrepreneurial spirit. Through systematic managerial practices such as skill training, information sharing, involvement in decision-making processes and authorization, companies influence entrepreneurial behaviors and therefore improve the level of organizational entrepreneurial orientation (Schuler 1986; Zhu and Chen 2014). Specifically, we argue that strategic human resource management, namely 
high performance work systems, can improve organizational entrepreneurial orientation, for the following reasons.

First, the large scale of investment in employees can improve their specialized knowledge and work-related skills, thus organizational human capital is enlarged (Youndt et al. 1996). As human capital drives the level of innovation and knowledge and skills are essential sources of innovation (Amabile et al. 1996; Wiersema and Bantel 1992), organizational entrepreneurial orientation can consequently be improved.

Second, practices such as autonomy and participation in decision-making processes encourage employees to break through current problem-solving patterns, search for entrepreneurial opportunities and take risks to try new approaches to get higher returns (Li et al., 2010; Wiklund and Shepherd 2005). Accumulated knowledge and risk-taking propensity can interact with each other and together facilitate entrepreneurial orientation.

Third, high performance work systems encourage the dimension of proactiveness because after employees obtain new knowledge, they will hope to use the knowledge to keep pace with current market trends. If they take actions ahead of competitors, they are more likely to gain first-mover advantages such as building relationships with customers and establishing distribution channels (Hughes and Morgan 2007; Wiklund and Shepherd 2005). Therefore, high performance work systems can accelerate proactive behaviors.

Furthermore, the implementation of HPWS creates an organizational innovative atmosphere through guiding and controlling the attitudes and behaviors of employees, consequently enhancing the level of organizational commitment and therefore improving innovation levels (Gittell et al. 2009; Herrmann and Felfe 2014). Specifically, through practices such as authorization, involvement in decision-making and payment share, employees can control work processes, have more autonomy to make decisions and cooperate better with teammates. Motivated to share weal and woe with firms (Lee and Bang 2012), employees become more loyal, hence organization commitment is improved. Therefore, employees are more inclined to innovate, take risks and generate new ideas (De Kok and Den Hartog 2006; Herrmann and Felfe 2014). In short, building the organizational atmosphere to encourage innovation, HPWS can improve the level of entrepreneurial orientation of the organization.

However, although theoretically demonstrated, few studies have empirically tested the effect of HPWS on firms' overall entrepreneurial orientation (Hayton 2005). In order to clarify the relationship between HPWS and entrepreneurial orientation, we assume that organizations can increase human capital and build an innovative atmosphere through a series of valid human resource management practices, thereby having a positive effect on organizational entrepreneurial orientation. Thus, Hypothesis 1 is stated as follows:

Hypothesis 1: High performance work systems have a positive effect on entrepreneurial orientation.

\section{Entrepreneurial orientation and corporate performance}

The essential function of entrepreneurial orientation in the performance of companies has been discussed extensively in the field of entrepreneurship (Wiklund 1999; 
Wiklund and Shepherd 2005). Companies with an entrepreneurial orientation are considered to have the ability to discover and exploit market opportunities ahead of their competitors (Lee et al. 2001; Wiklund and Shepherd 2003). However, previous research has shown confusing conclusions in the relationship between entrepreneurial orientation and corporate performance. Although plenty of empirical results show that firms with a higher level of entrepreneurial orientation often perform better than their counterparts (Clercq et al. 2010; Thanos et al. 2016; Wiklund and Shepherd 2005; Zahra and Covin 2015), some researchers find no positive relationship. For example, Runyan et al. (2008) point out the positive EO-performance relationship can be only confirmed in the growth stage rather than in later periods. Tang et al. (2008) suggest an inverted U-shape relationship between entrepreneurial orientation and corporate performance in the Chinese context. Messersmith and Wales (2013) suggest that EO-performance is not straightforward.

Complex results in the EO-performance relationship require deeper exploration and a more holistic perspective. The relationship between entrepreneurial orientation and corporate performance may be influenced by, among others, corporate culture, organizational structure, and/or external environment (Walter et al. 2006). This suggests the effect mechanism of entrepreneurial orientation should be put into a contingent condition, including environmental variables (complexity, dynamism and industrial cycle) and organizational variables (firm resources, organizational structure, etc.) (Covin and Slevin 1989; Lumpkin and Dess 1996). Therefore, we argue that when the external environment and internal organizational policies both encourage innovation and entrepreneurship, entrepreneurial orientation is positively related to organizational performance. Specifically, Chinese firms are facing fast environmental change in the economic transition period. In order to keep pace with emerging trends, companies need to start new businesses, create knowledge and break through current thinking patterns. Also, the Chinese government has implemented a series of policies to encourage entrepreneurial practices. Therefore, we assume a positive relationship between entrepreneurial orientation and corporate performance in this research.

As stated above, organizations with a higher level of entrepreneurial orientation express stronger inclinations towards innovativeness, willingness to take risks and proactiveness. These dimensions of entrepreneurial orientation improve the capabilities of the company. Firstly, the dimension of innovativeness encourages companies to update managerial methods, improve manufacturing modes, expand new markets and launch new products and services. In this way, organizations continuously improve efficiency and effectiveness and enhance abilities. These abilities are valuable and inimitable, because they are rooted in the organizational context and are thus difficult to be transplanted or imitated (Hunt and Arnett 2006; Nonaka 1994).

Companies' risk-taking behaviors can influence entrepreneurial choices (Dew et al. 2009). Entrepreneurs should consider potential loss when investing in new businesses (Miller 2007). The risk-taking dimension can be viewed as the willingness to take risks, break current approaches and explore potential opportunities to gain higher returns (Li et al. 2010; Wiklund and Shepherd 2005). Therefore, the risk-taking dimension helps firms improve the possibility of higher payback.

Timely actions are especially important when firms are faced with fluctuating environments. Proactiveness can help firms gain first-mover advantages (Hughes and 
Morgan 2007). With perspective and strategic foresight, companies tend to become first movers and achieve advantageous market positions such as brand popularity, distribution channels and high profits (Hunt and Arnett 2006; Lee et al. 2001; Wiklund and Shepherd 2005). Furthermore, companies with proactiveness are more likely to build intimate relationships with their suppliers and customers, which can provide vital resources and information (Marino et al. 2002; Messersmith and Wales 2013). Therefore, these firms can keep their market positions ahead of rivals and improve corporate performance.

Based on this analysis, we argue that the three dimensions of entrepreneurial orientation can enhance firm performance in different ways. Therefore, we propose that in a dynamic and changing environment, entrepreneurial orientation can benefit organizational outcomes. Hypothesis 2 is stated as follows:

Hypothesis 2: Entrepreneurial orientation is positively related to corporate performance.

\section{The intermediary role of entrepreneurial orientation}

Successful implementation of HPWS is vital to the improvement of corporate performance. However, despite much discussion about the financial and non-financial results HPWS can bring, the internal effect mechanism has not yet been clarified (Laursen and Foss 2003). Some researchers suggest that the relationship between HPWS and corporate performance may be more complicated than a single main effect (Way and Johnson 2005; Wei and Lau 2010). This call requires scholars to investigate thoroughly the potential mediating effect in the relationship between HPWS and corporate performance.

According to the aforementioned analysis, HPWS integrates single human resource practices into a synergic system, which is deeply embedded inside the organization. A resource-based view suggests these systems are heterogeneous, inimitable and valuable, and thus help organizations achieve sustained competitive advantages (Becker and Huselid 2006). Through the process of social exchange, the investment in human capital improves employees' perception of organizational support, thus enhancing the level of organizational commitment (Gittell et al. 2009). In return, employees display more supportive social behaviors and subsequently improve the overall performance of the organization (Ehrnrooth and Björkman 2012; Xiao and Björkman 2006).

More specifically, through strict recruiting procedures, scientific training systems, transparent promotion channels, and open information sharing, the investment in employees enlarges human capital and provides staff with knowledge and work-related skills, which are essential sources of innovation (Youndt et al. 1996). At the same time, through authorization and involvement in decision-making processes, HPWS enhances organizational commitment and creates an organizational atmosphere that encourages innovative behaviors (De Kok and Den Hartog 2006; Herrmann and Felfe 2014). In other words, with the implementation of HPWS, employees acquire greater control of their work, feel more loyal to their companies, and therefore become more incentivized to optimize their working methods, generate new ideas and take risks. Consequently, the company's overall innovation and the risk-taking level is improved (Herrmann and Felfe 2014). Since entrepreneurial orientation is a driving factor in firms' innovation (Wang et al. 2015), it might be a basic managerial approach to support and facilitate 
HPWS. With stronger inclinations towards innovativeness, risk-taking and proactiveness, companies tend to continuously improve managerial methods, update manufacturing technologies, take risks to launch new products and become first movers to achieve advantageous market positions (Hunt and Arnett 2006; Lee et al. 2001; Wiklund and Shepherd 2005). Therefore, companies with stronger entrepreneurial orientations are more likely to act ahead of their competitors and outperform counterparts (Clercq et al. 2010; Thanos et al. 2016).

As stated in Hypothesis 1 and Hypothesis 2, entrepreneurial orientation links the relationship between HPWS and corporate performance, which indicates the indirect effect mechanism of HPWS on corporate performance. Hence, we argue that HPWS is an antecedent of entrepreneurial orientation and may contribute to a firm's performance. In other words, HPWS help promote corporate performance by raising the corporate entrepreneurial orientation level. Based on this discussion of HPWS, entrepreneurial orientation and corporate performance, we propose Hypothesis 3 in the following statement:

Hypothesis 3: Entrepreneurial orientation mediates the relationship between high performance work systems and corporate performance.

\section{The moderating role of organizational learning}

Organizational learning was first accepted as a process through which organizations find and correct mistakes and reconstruct their knowledge base (Argyris and Schön 1997). Over the past few decades, scholars have constantly enriched and deepened the literature in this field. At present, organizational learning can be regarded as a "dynamic process of creating, acquiring and integrating knowledge to develop resources and capabilities that will enable the organization to achieve better performance" (Hassan and Alhakim 2011; Sanzo et al. 2012). A firm's ability to extract lessons from both successes and failures and generate new insights is conducive to performance (Senge 1990; Wang 2008). Therefore, organizational learning is widely considered as the most influential factor in firm success, and the ability to learn faster than competitors may be the only source of sustainable competitive advantage (Dickson 1992).

From the process perspective, sub-processes of organizational learning include training, information gathering, interpretation, retaining, transferring, and organizational memory (Argote 2012; Liu and Ko 2012). From a knowledge-searching and innovation perspective, organizational learning can be classified into exploitation learning and exploration learning, and balancing them helps organizations adapt to changing environments and gain competitive advantage (Kane and Alavi 2007; Lee and Huang 2012; March 1991). Empirical results show that organizational learning is positively related to financial and non-financial performance (Dibella et al. 1996; Goh et al. 2012; Luxmi 2014) and becomes a long-term influential mechanism in firms (Jiang et al. 2014).

With organizational learning in place, HPWS can be effectively implemented to improve corporate performance. As organizational learning includes training, information gathering, interpretation, retaining, transferring, and organizational memory (Argote 2012; Liu and Ko 2012), HPWS can be understood by employees and be easily instilled into their 
mindsets. They will take the initiative to absorb, learn and share knowledge, apply knowledge to their work and create new ideas (Fu et al. 2015).

This effective learning process enables organizations to quickly grasp, transfer, spread knowledge among employees and make it internalized in organizations. As these actions are valuable, rare and inimitable, organizations can obtain competitive advantages, adapt to dynamic environments and thus outperform their competitors. In this way, organizational structure can be improved and managerial practices can be better felt, absorbed and used, thus improving corporate performance. In contrast, when organizational learning is neglected, an organization can neither capture knowledge nor encourage employees to participate in the implementation of HPWS. The effect of HPWS on corporate performance will be weakened (Liao and Wu 2010).

Therefore, we suggest that when organizations have strong learning capabilities, HPWS will be more effectively implemented, hence corporate performance can be improved. Accordingly, we have developed Hypothesis 4:

Hypothesis 4: The relationship between high performance work systems and corporate performance is more positive when organizational learning is stronger.

\section{Methods}

\section{Sample and data collection}

The data for this study were gathered by surveying CEOs, presidents, or other top executives from firms in the manufacturing or service industries using 5-point Likert Scales. To ensure the reliability and validity of the study, we adopted mature research scales to test key variables. As all scales were originally in English, we translated them into Chinese and back-translated them to ensure the accuracy of the scales. In order to avoid unnecessary ambiguity in meaning, we randomly selected executives and carefully explained each item to them. According to the feedback, we slightly adjusted inappropriate items, added more fact-based questions (Chang et al. 2010), cut some questions into short and clear sentences to improve cognitive effort and weaken the possibility of transient mood states such as boredom (Lindell and Whitney 2001).

Two groups of founders, partners, or top executives of companies took part in executive training courses at a university. One group was present in mid-October and the other group in early November, 2017. We obtained the participants' background information, such as their names, company names and their positions because one of the researchers was involved in teaching a 2-day class with each group. This enabled us to conduct an initial screening to exclude those who worked in non-business organizations or who were not in key executive positions in companies and identify the ideal respondents to answer the questionnaire.

The researchers asked the qualified candidates to participate in this study without providing any incentives. We communicated with them face-to-face about the purposes and content of this research and provided detailed on-site instruction on how to answer the questionnaire. We encouraged them to invite their friends who were either founders or top executives of other companies to participate in this survey.

The researcher also held seminars on the research topic for three different executive gatherings and distributed the questionnaire among them. For all those who participated 
in this survey, we not only assured them of the confidentiality and anonymity of their responses, preventing their answers from being interfered by social expectations (Podsakoff et al. 2003), but also promised to share with them the findings of this research.

We took a number of steps to minimize the effects of common method variance (Ambos et al. 2013; Lindell and Whitney 2001; Podsakoff et al. 2003). First, we improved the scale items by using multiple item constructs and different scale formats. Second, we rearranged the order of the survey items. Third, each respondent was required to ask another executive who was in charge of finance in the same company to fill in the performance part.

We distributed more than 450 questionnaires in total from early September to midNovember, 2017. These efforts finally yielded 212 responses. After deleting those with missing values or incomplete answers, we finally obtained 176 valid responses from 134 firms. The effective response rate was $39.11 \%$. We compared the mean and standard deviation of some key variables such as firm size, firm location and the industry of the 134 firms with those of the sampled 450 firms and did not find significant differences.

Of the sampled enterprises, 59.2\% have a history of more than 10 years. The longer the history is, the more attention will be paid to the construction of the HR management system. The data from these enterprises improves the reliability of the survey. As for ownership type, $18.4 \%$ are state-owned companies, $71.14 \%$ are privately owned companies and the rest are foreign companies or joint ventures. $26.87 \%$ of the firms are publicly listed and $73.13 \%$ are not listed firms. Among all the firms that participated in the survey, $61.36 \%$ are in the manufacturing industry and $38.64 \%$ are in the service industry.

\section{Variable measures}

High performance work systems (HPWS)

Although the measurement of HPWS has not reached a consensus among scholars, most scales share some common points: work design, promotion mechanism, skill training, level of employee commitment, communication, motivation, etc. (Appelbaum et al. 2000; Pfeffer 1996; Posthuma et al. 2013). Since the strategic human resource management literature suggests HPWS take effect as a whole (Delaney and Huselid 1996), in this study we regard HPWS as a single dimension concept and discuss its relations with other variables. We adopt the scale designed by Su (2010), which contains the common points of most scales. Sample items include "There is a standardized training system inside the company"; "This company offers key talents competitive payments" etc.

\section{Entrepreneurial orientation}

This study uses the 9-item measurement of entrepreneurial orientation proposed by Covin and Slevin (1989). The scale consists of three dimensions: innovation, proactiveness and risk-taking. Many studies have confirmed its usefulness and accuracy in different situations (Hansen et al. 2009; Kreiser et al. 2002). The 'Covin scale' has been verified in more than 20,000 enterprises and 7 different cultural background contexts. As well, to be consistent with Stam and Elfring (2015), we treat entrepreneurial orientation as a whole concept to explore its influence on HPWS and corporate performance. Sample survey items are as follows: "In the last 3 years, there are many changes of the 
products and services of the company"; "In general, this company emphasizes research, technology and innovation" etc.

\section{Organizational learning}

Researchers have designed different scales to explain organizational learning from different perspectives. We adopt the scale developed by March (1991), which consists of 10 items. Sample items include: "Our aim was to search for information to refine common methods and ideas in solving problems in the project"; "We preferred to collect information with no identifiable strategic market needs to ensure experimentation in the project" etc.

\section{Corporate performance}

In this research, corporate performance is measured by the growth of sales, growth of assets, growth of market valuation, and growth of net profits by comparing this year's data with those in the previous year.

We did not use absolute financial data because some companies were reluctant to report them. We knew from private conversations with some executives that their major concerns with disclosing financial data were the possible influences on their public offerings in IPOs. Others also had some concerns about taxes. Besides, some companies had strict regulations for disclosing data.

Therefore, instead of absolute data, a comparison of this year's absolute financial data with that in the previous year is used to enable us to capture the growth of the company. This calculation is based on the objective financial data within 2 years.

\section{Control variables}

Firm size is controlled as large firms are more likely to establish HPWS due to scale (Datta and Wright 2005). The number of employees (log transformed) is used to represent firm size. In addition, industry category ( 0 for manufacturing and 1 for service) is controlled because growth patterns differed in different industries (Datta and Wright 2005; Guthrie 2001). Following the research of Guthrie (2001), we also treat ownership type, firm age, listed or not as control variables.

\section{Analysis and results}

Test of reliability and validity

Analysis of reliability is to verify the stability and consistency of the measurement result. In empirical studies, Cronbach's alpha analysis is widely applied to measure the inner stability and consistency of the Likert Scale. Generally speaking, the $\alpha$ value of Cronbach should be higher than 0.7 , and it proves very strong reliability when the $\alpha$ value is higher than 0.9 , see Table 1 .

As is shown in Table 1, the Cronbach's $\alpha$ for HPWS, organizational learning and corporate performance are all above 0.9 , which reflects strong reliability. The Cronbach's $\alpha$ value of entrepreneurial orientation is 0.809 , which also reflects a high level of reliability.

This study aims to explore the relationship between HPWS and corporate performance. Therein entrepreneurial orientation and organizational learning are considered to be single dimensional. The widely used method for validity analysis is factor analysis. To test whether the items suit exploratory factor analysis, we apply the KMO method 
Table 1 Construct Reliability

\begin{tabular}{lll}
\hline Concept & Number of subjects & Cronbach's a Coefficient \\
\hline High Performance Work Systems & 25 & 0.948 \\
Entrepreneurial Orientation & 9 & 0.809 \\
Organizational Learning & 10 & 0.922 \\
Corporate Performance & 4 & 0.902 \\
\hline
\end{tabular}

and Barlett's sphericity test. Generally, when the KMO value is above 0.7 , factor analysis can be used.

Table 2 shows that KMO values of HPWS and organizational learning are above 0.9. The KMO value of entrepreneurial orientation and corporate performance is higher than 0.8. Furthermore, the effect of Barlett's sphericity is significant. The results meet the requirement of exploratory factor analysis. The accumulative explained variances are respectively $66.948,61.917,59.127,77.445 \%$, which suggests the construct validity of the model is high.

We use the average variance extracted (AVE) to assess the main variables. Results show that the AVE value of high performance work systems, entrepreneurial orientation, organizational learning, and corporate performance are 0.650, 0.722, 0.692 and 0.774 respectively. All AVE values are above 0.5 , which indicates the high convergent validity of the variables.

In order to confirm constructs discriminant validity, we use AMOS 22.0 to conduct confirmatory factor analysis. Results are shown in Table 3. We compare the four-factor model with a three-factor model, a two-factor model and a single-factor model. Typically, if $x^{2} / d f<5$, IFI $>0.9$, CFI $>0.9$, RMSEA $<0.08$, the variables have high discriminant validity. Results show that the four-factor model has the highest model fit $\left(\chi^{2}(48)=\right.$ 87.334, IFI $=0.977, \mathrm{CFI}=0.977$, RMSEA $=0.068$ ).

\section{Descriptive statistics and correlations}

Before regression analysis, we carry out descriptive statistics analysis and correlation analysis. As Table 4 shows, the mean value of HPWS is 3.75, which suggests sampled enterprises attach importance to HR management. The average value of entrepreneurial orientation is 3.13, which indicates that the enterprises also care for their innovation capability, risk affordability and prospective improvement. Organizational learning and corporate performance are also above average. Further, the Spearman correlation coefficient matrix shows a significant positive correlation among variables, which provides a good basis for regression analysis.

In order to check the collinearity of variables, we calculate the variance inflation factor (VIF) value of the independent variables. Results show that the VIF values of

Table 2 Construct Validity

\begin{tabular}{llll}
\hline Constructs & KMO Value & Barlett Sphericity Test & Accumulative Explained Variances \\
\hline High Performance Work Systems & 0.917 & 0.000 & $66.948 \%$ \\
Entrepreneurial Orientation & 0.802 & 0.000 & $61.917 \%$ \\
Organizational Learning & 0.907 & 0.000 & $59.127 \%$ \\
Corporate Performance & 0.818 & 0.000 & $77.445 \%$ \\
\hline
\end{tabular}


Table 3 Confirmatory Factor Analysis

\begin{tabular}{lllllll}
\hline Model & $x^{2}$ & $d f$ & $x^{2} / d f$ & IFI & CFI & RMSEA \\
\hline Four-factor model: HPWS, EO, OL, CP & 87.334 & 48 & 1.819 & 0.977 & 0.977 & 0.068 \\
Three-factor model: HPWS, EO + CP, OL & 324.072 & 51 & 6.354 & 0.841 & 0.839 & 0.175 \\
Three-factor model: HPWS, EO + OL, CP & 265.757 & 51 & 5.211 & 0.875 & 0.873 & 0.155 \\
Three-factor model: HPWS+EO, OL, CP & 285.036 & 51 & 5.589 & 0.864 & 0.862 & 0.162 \\
Two-factor model: HPWS+OL, EO + CP & 592.977 & 53 & 11.188 & 0.686 & 0.681 & 0.241 \\
Single-factor model: HPWS+OL + EO + CP & 816.311 & 54 & 15.117 & 0.556 & 0.550 & 0.284
\end{tabular}

HPWS high performance work systems; $E O$ entrepreneurial orientation; $O L$ organizational learning; $C P$ corporate performance; IFI incremental fit index; CFI the comparative fit index; RMSEA root-mean-square error of approximation

HPWS, EO and OL are 1.688, 1.763 and 1.503 respectively, which indicates that the degree of multi-collinearity of variables is low.

\section{Regression analysis}

The hypotheses tests should include three parts: the main effect, the mediating effect and the moderating effect.

Firstly we put in control variables to create Model 1 and then add independent variable HPWS to formulate Model 2. As illustrated in Table 5, after taking HPWS into consideration, the explanatory power of Model 2 is significantly improved with $\triangle F=$ 7.333 and $P<0.001$. Hence HPWS has a significantly positive relationship with corporate performance.

According to Baron and Kenny (1986), four prerequisites are needed for the verification of mediation effects: (1) positive effects of HPWS on corporate performance; (2) positive effects of HPWS on entrepreneurial orientation; (3) positive effects of entrepreneurial orientation on corporate performance; (4) taking entrepreneurial orientation into consideration, if the positive relationship between HPWS and corporate performance is dropped, entrepreneurial orientation has partial mediating effects. If the effect of HPWS on corporate performance becomes no longer significant, it suggests the full mediating role of entrepreneurial orientation.

Following the above instructions, we test the mediation effects of entrepreneurial orientation in the HPWS-performance relationship. Results are shown in Table 5.

Table 4 Descriptive Statistics, Reliability Coefficients and Correlation Matrix $(N=176)$

\begin{tabular}{llllllllllll}
\hline Variable & average & S.D. & 1 & 2 & 3 & 4 & 5 & 6 & 7 & 8 & 9 \\
\hline 1. Firm size & 5.48 & 2.26 & 1 & & & & & & & \\
2. Industry Type & 0.39 & 0.49 & $-0.191^{*}$ & 1 & & & & & & \\
3. Listed & 1.72 & 0.45 & $-0.545^{* *}$ & $0.163^{*}$ & 1 & & & & & \\
4. Firm age & 2.49 & 1.06 & $0.572^{* *}$ & -0.106 & $-0.457^{* *}$ & 1 & & & & \\
5.Ownership & 1.93 & 0.55 & 0.015 & $-0.369^{* *}$ & -0.124 & -0.059 & 1 & & & \\
6. HPWS & 3.75 & 0.66 & 0.058 & 0.013 & $-0.207^{* *}$ & -0.085 & 0.147 & 1 & & \\
7. EO & 3.14 & 0.66 & 0.012 & 0.003 & -0.066 & $-0.267^{* *}$ & 0.114 & $0.450^{*}$ & 1 & & \\
8. OL & 3.89 & 0.69 & 0.036 & 0.050 & $-0.193^{* *}$ & -0.117 & 0.026 & $0.594^{* *}$ & $0.490^{*}$ & 1 & \\
9. CP & 3.67 & 0.77 & $0.273^{* *}$ & -0.020 & $-0.387^{* *}$ & 0.095 & 0.092 & $0.496^{* *}$ & $0.350^{* *}$ & $0.326^{* *}$ & 1 \\
\hline
\end{tabular}

HPWS high-performance work systems; $E O$ entrepreneurial orientation; $O L$ organizational learning ${ }^{*} p<0.05 ;{ }^{* *} p<0.01$ (two-tailed tests) 
Table 5 Regression Results: HPWS, Entrepreneurial Orientation and Corporate Performance (Hypotheses 1, 2 \& 3)

\begin{tabular}{|c|c|c|c|c|c|c|}
\hline \multirow[t]{2}{*}{ DV } & \multicolumn{4}{|c|}{ Corporate Performance } & \multicolumn{2}{|c|}{ Entrepreneurial Orientation } \\
\hline & Model 1 & Model 2 & Model 3 & Model 4 & Model 5 & Model 6 \\
\hline Firm size & 0.061 & 0.054 & 0.042 & 0.045 & 0.053 & 0.045 \\
\hline Industry type & 0.125 & 0.080 & 0.102 & 0.077 & 0.065 & 0.013 \\
\hline Listed & $-0.627^{* * *}$ & $-0.436^{* *}$ & $-0.538^{* * *}$ & $-0.424^{* *}$ & -0.242 & -0.058 \\
\hline Firm age & $-0.120^{*}$ & -0.058 & -0.020 & -0.016 & $-0.273^{* * *}$ & $-0.204^{* *}$ \\
\hline Ownership & 0.088 & 0.012 & 0.051 & 0.004 & 0.099 & 0.041 \\
\hline HPWS & & $0.496^{* * *}$ & & $0.413^{* * *}$ & & $0.402^{* * *}$ \\
\hline EO & & & $0.365^{* * *}$ & $0.206^{*}$ & & \\
\hline F & $7.500^{* * *}$ & $14.833^{* * *}$ & $10.253^{* * *}$ & $13.967^{* * *}$ & $5.475^{* * *}$ & $10.350^{* * *}$ \\
\hline$\Delta F$ & - & $7.333^{* * *}$ & $2.753^{* * *}$ & $3.714^{* * *}$ & - & $4.875^{* * *}$ \\
\hline$R^{2}$ & 0.181 & 0.348 & 0.267 & 0.371 & 0.139 & 0.271 \\
\hline$\Delta R^{2}$ & - & 0.167 & 0.086 & 0.104 & - & 0.132 \\
\hline Mean VIF & 1.46 & 1.44 & 1.46 & 1.49 & 1.46 & 1.44 \\
\hline
\end{tabular}

HPWS High performance work systems; EO Entrepreneurial orientation ${ }^{*} p<0.05 ;{ }^{* *} p<0.01$ (two-tailed tests)

Step one: the relationship between HPWS and corporate performance. As shown in the previous section, HPWS have a positive influence on corporate performance. The first precondition is fulfilled.

Step two: the relationship between HPWS and entrepreneurial orientation. In Model 5 we regard entrepreneurial orientation as a dependent variable and put in control variables. Then we add HPWS as an independent variable to create Model 6 . The explanatory power of Model 6 increases significantly as $\Delta F$ equals $4.875, P<0.001$. The $\beta$ index of HPWS towards entrepreneurial orientation is $0.402(P<0.001)$ and $\Delta R^{2}$ equals 0.132 , which shows that HPWS has positive effects on entrepreneurial orientation. Hypothesis 1 is confirmed.

Step three: the relationship between entrepreneurial orientation and corporate performance. In Model 3 we regard corporate performance as the dependent variable and add control variables and then put in entrepreneurial orientation as the independent variable. Taking entrepreneurial orientation into consideration, $\Delta F=2.753,(P<0.001)$, $\Delta R^{2}=0.086$, which indicates that entrepreneurial orientation has a positive effect on corporate performance. This result support Hypothesis 2.

Step four: the mediating effect of entrepreneurial orientation between HPWS and corporate performance. We add corporate performance, HPWS, entrepreneurial orientation and control variables to get Model 4 . After adding the mediating variable into the model, $\Delta F=3.714, P<0.001$. However, the $\beta$ index between HPWS and Firm performance declined from $0.496(P<0.001)$ to $0.413(P<0.001)$, which indicates the correlation between HPWS and corporate performance is weakened. As discussed above, entrepreneurial orientation acts as a partial mediating variable between HPWS and corporate performance. Hypothesis 3 is therefore partially supported.

The process to test the moderating effect of organizational learning should include three steps (Baron and Kenny 1986): (1) test the effect of HPWS and organizational learning on corporate performance to get $R 1^{2}$; (2) build the product term of HPWS and organizational learning and then perform regression analysis including corporate 
performance, HPWS, organizational learning and their product-term to get $R 2^{2}$; (3) compare the value of $R 2^{2}$ with the value of $R 1^{2}$. The greater value of $R 2^{2}$ suggests the moderating effect of organizational learning in the relationship between HPWS and corporate performance.

We firstly standardize the independent variable and moderating variable, then get the interaction term by multiplying the standardized HPWS with organizational learning. Last, we perform a regression for these variables. Results are presented in Table 6 .

To verify the independent effect of HPWS and organizational learning, control variables are inputted into Model 7. Then we add HPWS and organizational learning in Model 8. $R^{2}$ is 0.181 in Model 7. After taking independent and moderating variables into consideration, $R^{2}$ is lifted to 0.348 . The explanatory power is obviously strengthened $(\Delta F=5.149, p<0.001)$. After we introduce the interaction term in Model 9, in which $R^{2}$ equals 0.366 , the explanatory power is obviously increased too $(\Delta F=4.383$, $p<0.001$ ). Since $R^{2}$ of Model 9 is greater than $R^{2}$ of Model 8 , we conclude that organizational learning can positively moderate the relationship between HPWS and corporate performance. The different moderating effects of organizational learning at high and low levels are illustrated in Fig. 2.

\section{Robustness check}

In order to check the robustness of our results, we also use another measurement of corporate performance. We synthesize the performance scales designed by Dyer and Reeves (1995), Cheng and Zhao (2011). Sample items are as follows: "Compared to the two main competitors, the return on assets of our firm is high". "Compared to the two main competitors, the market share of our firm is high". This scale includes 6 items, asking the participants to compare their company's performance with those of their two main competitors in the industry. Since industry usually has a huge impact on a

Table 6 Moderating Effect Regression Results (Hypothesis 4)

\begin{tabular}{llll}
\hline Corporate Performance & & & \\
\hline Firm size & Model 7 & Model 8 & Model 9 \\
Industry type & 0.061 & 0.054 & 0.059 \\
Listed & 0.125 & 0.079 & 0.117 \\
Firm age & $-0.627^{* * *}$ & $-.432^{* * *}$ & -0.406 \\
OWnership & $-0.120^{*}$ & -0.056 & -0.063 \\
HPWS & 0.088 & 0.014 & 0.035 \\
OL & & $0.484^{* * *}$ & $0.459^{* * *}$ \\
HPWS ${ }^{*} O L$ & & 0.020 & 0.024 \\
$R^{2}$ & & $0.210^{*}$ & \\
$\Delta R^{2}$ & 0.181 & 0.3480 .366 & \\
$F$ & - & 0.1670 .185 & $11.883^{* *}$ \\
$\Delta F$ & $7.500^{* * *}$ & $12.649^{* * *}$ & $4.383^{* * *}$ \\
Mean VIF & - & $5.149^{* * *}$ & 1.50 \\
\hline HPWS High performance work systems; OL organizational learning & 1.55 &
\end{tabular}




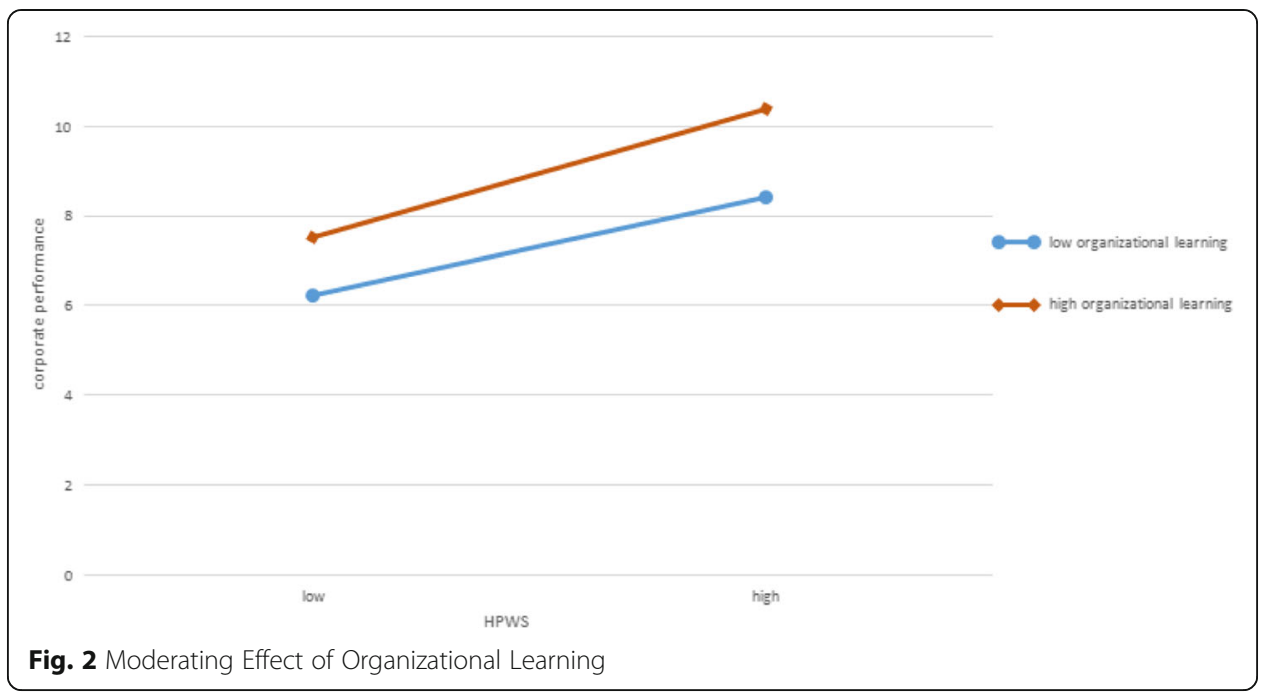

focal company, it is reasonable to compare the performance level to the average level of an industry. Empirical results support all the hypotheses.

\section{Discussion}

\section{Conclusions}

This study explores the relationship between HPWS and corporate performance and the effect mechanism of HPWS. Through the empirical data analysis, we come to the following conclusions:

First, our empirical evidence shows HPWS can be regarded as an antecedent variable of entrepreneurial orientation. Through a series of managerial methods, organizations can improve the level of innovativeness, risk-taking inclination and proactiveness. Therefore, the companies constantly update manufacturing skills, grasp market opportunities and create new ideas and products, and thus outperform their competitors.

Second, we find that entrepreneurial orientation can positively influence corporate performance. Companies with a higher level of entrepreneurial orientation tend to update managerial patterns, launch new products, answer to market changes quickly and adjust strategic decisions ahead of competitors. Therefore, these companies can obtain competitive advantages and improve corporate performance.

Third, our work reveals that entrepreneurial orientation partially mediates the relationship between HPWS and corporate performance. This indicates the indirect effect mechanism of HPWS on corporate performance. HPWS helps promote corporate performance by raising the corporate entrepreneurial orientation level. The improved entrepreneurial orientation can further enhance firm performance.

Finally, we find that organizational learning positively moderates the relationship between HPWS and corporate performance. When an organization has a high level of learning capability, employees will acquire, utilize and share knowledge more actively. In this way, HPWS can be more effectively implemented. In contrast, a lower level of organizational learning will weaken the effect of HPWS on corporate performance. 


\section{Theoretical Contributions}

This research contributes to the theoretical developments in the following way. First, by answering the calls of previous studies (Laursen \& Foss, 2003; Lee \& Bang, 2012), this paper explores the inherent effect mechanism of the HPWS-performance relationship at the organizational level. Prior studies have not clearly unraveled the effect process of HPWS on corporate performance (Way \& Johnson, 2005; Wei \& Lau, 2010). This work has extended our understanding of the relationship between HPWS and corporate performance and has dived deeper into the effect process, and therefore contributes to the theoretical development of human resource management.

Second, previous research focusing on the antecedents of entrepreneurial orientation have argued that human resource management practices can facilitate the level of organizational entrepreneurial spirit (De Kok \& Den Hartog, 2006; Gittel et al., 2009; Herrmann \& Felfe, 2014). However, these arguments are largely based on theoretical assumptions and lack empirical tests (Schmelter et al., 2010). This exploration is a beneficial supplement to entrepreneurship theory.

Third, past research (Gutpa \& Batra, 2016; Rauch et al. 2009; Thanos, et al., 2016) has attached great importance to the EO-performance relationship and paid little attention to the mediation effect of entrepreneurial orientation between HPWS and corporate performance. This study has revealed that heavy investment in human capital can promote knowledge, innovation and cooperation of employees, therefore improving the level of organizational entrepreneurial orientation. Our study emphasizes the important role of organizational entrepreneurial spirit in organizational management and is a beneficial attempt to combine human resource management and entrepreneurship practices.

Finally, our findings reveal the moderating role in the research of organizational learning and are consistent with past research (e.g., Fu et al., 2015; Liao \& Wu, 2010). The results shed light on the interaction effect of human resource practices and organizational learning practices.

\section{Managerial implications}

This research also has some practical implications. First, managers should attach importance to investment in human capital and introduce HPWS to improve corporate performance. Through strict recruiting procedures, specific training, clear career development plans, friendly job environments, authorization, information sharing and fair pay systems, companies can attract professional employees, enhance their knowledge and skills, and improve the level of their autonomy and commitment. Thus, employees are motivated to adjust their work to corporate strategy, create new ideas and take risks. A living company is therefore created.

Second, this study suggests entrepreneurial orientation can help companies find potential opportunities to expand markets and customers. As the accelerated process of marketization and social and economic transformation bring a series of opportunities and challenges, companies should improve the level of entrepreneurial orientation to enhance corporate value by adopting new technology and managerial methods, taking risks in dynamic environments and taking actions ahead of competitors. 
Third, managers may combine HPWS and entrepreneurial orientation in order to enhance corporate performance, as this research has demonstrated so far. While HPWS emphasizes internal managerial practices, entrepreneurial orientation is more about the attitude towards the outside. Ideally, managers would combine and balance both approaches.

Finally, the successful implementation of HPWS is related to organizational learning. If companies pay no attention to organizational learning, HPWS would not be approved or effectively implemented, thus the promotion effect on corporate performance would be weakened. Firms should take organizational learning seriously, build internal knowledge systems, create learning atmospheres and encourage employees to explore, learn and share knowledge. Therefore, every managerial practice can be more efficiently and effectively implemented.

\section{Limitations and further research}

Despite the contributions of this study, there still remain some limitations, which may indicate avenues for future research. First, the sample resources can be improved. In this research, sample data is cross-sectional, which may not adequately reflect the causal relationship among variables. Future research can introduce panel data to avoid potential disadvantages. Second, the research level can be extended. This study explores the effect of HPWS on corporate performance at the organizational level. However, past research has found HPWS can also influence individual performance such as employee satisfaction, turnover rate, employee creativity, etc. Future studies may add employee performance as individual-level variables and adopt a hierarchical linear model to deeply explore the relationship between HPWS and corporate performance.

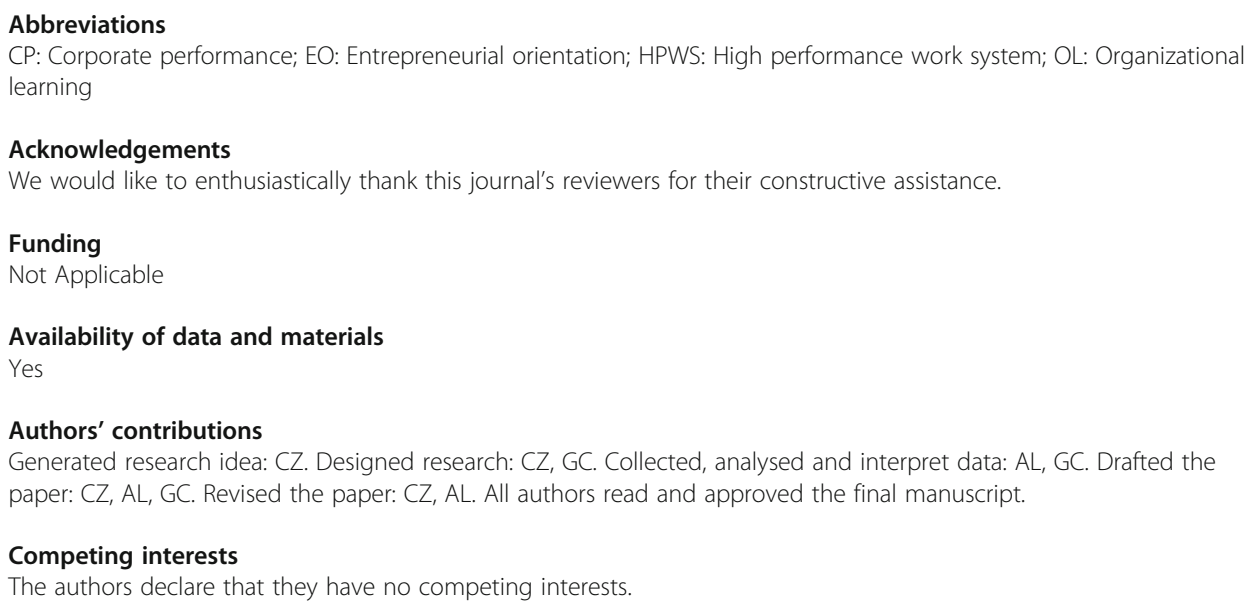

\section{Publisher's Note}

Springer Nature remains neutral with regard to jurisdictional claims in published maps and institutional affiliations.

Author details

${ }^{1}$ Renmin University of China, Beijing 100872, China. ${ }^{2}$ Shanghai Provident Center, Shanghai 200003, China.

Received: 21 May 2017 Accepted: 31 January 2018

Published online: 28 February 2018

\section{References}

Amabile, T. M., Conti, R., Coon, H., Lazenby, J., \& Herron, M. (1996). Assessing the work environment for creativity. Academy of Management Journal, 39(5), 1154-1184.

Ambos, T. C., Nell, P. C., \& Pedersen, T. (2013). Combining stocks and flows of knowledge: The effects of intra-functional and cross-functional complementarity. Global Strategy Journal, 3(4), 283-299. 
Appelbaum, E., Bailey, T., Berg, P., \& Kalleberg, A. L. (2000). Manufacturing advantage: Why high-performance work systems pay off. Academy of Management Review, 26(3), 345-347.

Argote, L. (2012). Organizational learning research: Past, present and future. Development and Learning in Organizations, 23(2), 175-178.

Argyris, C., \& Schön, D. A. (1997). Organizational learning: A theory of action perspective. Reis, (77/78), 345-348. Barney, J. B. (1991). Firm resource and sustained competitive advantage. Journal of Management, 17(1), 99-120.

Baron, R. M., \& Kenny, D. A. (1986). The moderator-mediator variable distinction in social psychological research: Conceptual, strategic, and statistical considerations. Journal of Personality and Social Psychology, 51(6), 1173.

Bashir, M., Jianqiao, L., Ghazanfar, F., \& Abrar, M. (2012). The effect of perception of existence of HPWS on employee's organizational commitment: A test of social exchange relationship and contingency perspective to implement HPWS in universities of China and Pakistan. Advances in Asian Social Science, 1(1), 87-98.

Batt, R., \& Colvin, A. J. (2011). An employment systems approach to turnover: Human resources practices, quits, dismissals, and performance. The Academy of Management Journal, 54(4), 695-717.

Becker, B. E., \& Huselid, M. A. (2006). Strategic human resource management: Where do we go from here? Journal of Management, 32(6), 898-925.

Chang, S. J., Witteloostuijn, A. V., \& Eden, L. (2010). From the editors: Common method variance in international business research. Journal of International Business Studies, 41(2), 178-184.

Chen, C. J. (2009). Strategic human resource practices and innovation performance: The mediating role of knowledge management capacity. Strategic Direction, 62(6), 104-114.

Cheng, D. J., \& Wang, B. B. (2011). The relationship among high performance work system, personal trust and organizational citizenship behavior-The moderating effect of distributive justice. Chinese Journal of Management, 08(5), 727-733.

Cheng, D. J., \& Zhao, Y. (2011). The mechanism of high performance work system on enterprise performance: The mediating role of organizational trust. Soft Science, 25(4), 96-99.

Clercq, D. D., Dimov, D., \& Thongpapanl, N. (2010). The moderating impact of internal social exchange processes on the entrepreneurial orientation-performance relationship. Journal of Business Venturing, 25(1), 87-103.

Collins, C. J., \& Clark, K. D. (2003). Strategic human resource practices, top management team social networks, and firm performance: The role of human resource practices in creating organizational competitive advantage. The Academy of Management Journal, 46(6), 740-751.

Covin, J. G., \& Slevin, D. P. (1989). Strategic management of small firms in hostile and benign environments. Strategic Management Journal, 10(1), 75-87.

Datta, D. K., \& Wright, P. M. (2005). Erratum: Human resource management and labor productivity: Does industry matter? The Academy of Management Journal, 48(3), 135-145.

De Kok, J. M. P., \& Den Hartog, D. (2006). High performance work systems, performance and innovativeness in small firms. EIM Scales Paper, 200520.

Delaney, J. T., \& Huselid, M. A. (1996). The impact of human resource management practices on perceptions of organizational performance. The Academy of Management Journal, 39(4), 949-969.

Dew, N., Sarasathy, S., Read, S., \& Wiltbank, R. (2009). Affordable loss: Behavioral economic aspects of the plunge decision. Strategic Entrepreneurship Journal, 3(2), 105-126.

Dibella, A. J., Nevis, E. C., \& Gould, J. M. (1996). Understanding organizational learning capability. Journal of Management Studies, 33(3), 361-379.

Dickson, P. R. (1992). Toward a general theory of competitive rationality. Journal of Marketing, 56(1), 69-83.

Dyer, L., \& Reeves, T. (1995). Human resource strategies and firm performance: What do we know and where do we need to go? International Journal of Human Resource Management, 6(3), 656-670.

Edwards, P., \& Wright, M. (2001). High-involvement work systems and performance outcomes: The strength of variable, contingent and context-bound relationships. International Journal of Human Resource Management, 12(4), 568-585.

Ehrnrooth, M., \& Björkman, I. (2012). An integrative HRM process theorization: Beyond signalling effects and mutual gains. Journal of Management Studies, 49(6), 1109-1135.

Fu, N., Flood, P. C., Bosak, J., Morris, T., \& O'Regan, P. (2015). How do high performance work systems influence organizational innovation in professional service firms? Employee Relations, 37(2), 209-231.

Gittell, J. H., Seidner, R., \& Wimbush, J. (2009). A relational model of how high-performance work systems work. Organization Science, 21(2), 490-506.

Goh, S. C., Elliott, C., \& Quon, T. K. (2012). The relationship between learning capability and organizational performance. The Learning Organization, 19(2), 92-108.

Gupta, V. K., \& Batra, S. (2016). Entrepreneurial orientation and firm performance in Indian SMEs: Universal and contingency perspectives. International Small Business Journal, 34(5), 660-682.

Guthrie, J. P. (2001). High-involvement work practices, turnover, and productivity: Evidence from new zealand. The Academy of Management Journal, 44(1), 180-190.

Hansen, J., Dietz, G., Marino, L., Kreiser, P., \& Weaver, K. M. (2009). Measuring cross-natonal invariance of the entrepreneurial orientation scale. Frontiers of Entrepreneurship Research, 29(22), 3.

Hassan, S., \& Alhakim, L. A. Y. (2011). The relationships among critical success factors of knowledge management, innovation and organizational performance: A conceptual framework. International Proceedings of Economics Development \& Research.

Hayton, J. C. (2005). Promoting corporate entrepreneurship through human resource management practices: A review of empirical research. Human Resource Management Review, 15(1), 21-41.

Herrmann, D., \& Felfe, J. (2014). Effects of leadership style, creativity technique and personal initiative on employee creativity. British Journal of Management, 25(2), 209-227.

Hu, W. B., \& Zhang, Y. L. (2011). New enterprises' abilities to turn entrepreneurial orientation to performance: Theoretical model and Chinese empirical research. Nankai Business Review, 14(1), 83-95.

Hughes, M., \& Morgan, R. E. (2007). Deconstructing the relationship between entrepreneurial orientation and business performance at the embryonic stage of firm growth. Industrial Marketing Management, 36(5), 651-661. 
Hunt, S. D., \& Arnett, D. B. (2006). Does marketing success lead to market success? Journal of Business Research, 59(7), 820-828.

Huselid, M. A. (1995). The impact of human resource management practices on turnover, productivity, and corporate financial performance. The Academy of Management Journal, 38(3), 635-672.

Jiang, J. H., Liu, C. J., \& Jiang, T. Y. (2014). A meta-analysis of the relationship between organizational learning and corporate performance-Based on the moderating effect of measurement factors and contextual factors. Science Research Management, 35(8), 117-125.

Kane, G. C., \& Alavi, M. (2007). Information technology and organizational learning: An investigation of exploration and exploitation processes. Organization Science, 18(5), 796-812.

Khazanchi, S., \& Masterson, S. S. (2011). Who and what is fair matters: A multi-foci social exchange model of creativity. Journal of Organizational Behavior, 32(1), 86-106

Kinnie, N., Hutchinson, S., \& Purcell, J. (2000). 'Fun and surveillance': The paradox of high commitment management in call centres. International Journal of Human Resource Management, 11(5), 967-985.

Kreiser, P. M., Marino, L. D., \& Weaver, K. M. (2002). Assessing the psychometric properties of the entrepreneurial orientation scale: A multi-country analysis. Entrepreneurship Theory and Practice, 26(4), 71-71.

Laursen, K., \& Foss, N. J. (2003). New human resource management practices, complementarities and the impact on innovation performance. Cambridge Journal of Economics, 27(2), 243-263.

Lee, C., \& Huang, Y. (2012). Knowledge stock, ambidextrous learning, and firm performance. Management Decision, 50(6), 1096-1116

Lee, C., Lee, K., \& Pennings, J. M. (2001). Internal capabilities, external networks, and performance: A study on technology-based ventures. Strategic Management Journal, 22(6/7), 615-640.

Lee, J. W., \& Bang, H. (2012). High performance work systems, person-organization fit and organizational outcomes. Journal of Business Administration Research, 1(2), 129.

Li, Y., Zhao, Y., Tan, J., \& Liu, Y. (2010). Moderating effects of entrepreneurial orientation on market orientationperformance linkage: Evidence from Chinese small firms *. Journal of Small Business Management, 46(1), 113-133.

Liao, S. H., \& Wu, C. C. (2010). System perspective of knowledge management, organizational learning, and organizational innovation. Expert Systems with Applications, 37(2), 1096-1103.

Lindell, M. K., \& Whitney, D. J. (2001). Accounting for common method variance in cross-sectional research designs. The Journal of Applied Psychology, 86(1), 114-121.

Links, M. M., Mihail, D. M., \& Sarvanidis, S. (2013). High performance work systems in corporate turnaround: A German case study. Journal of Organizational Change Management, 26(1), 190-216.

Liu, G., \& Ko, W. W. (2012). Organizational learning and marketing capability development: A study of charity retailing operating of British social enterprises. Nonprofit and Voluntary Sector Quarterly, 41(4), 580-608.

Lumpkin, G. T., \& Dess, G. G. (1996). Clarifying the entrepreneurial orientation construct and linking it to performance. The Academy of Management Review, 21(1), 135-172.

Luxmi. (2014). Organizational learning act as a mediator between the relationship of knowledge management and organizational performance. Management \& Labour Studies, 39(1), 31-41.

March, J. G. (1991). Exploration and exploitation in organizational learning. Organization Science, 2(1), 71-87.

Marino, L., Strandholm, K., Steensma, H. K., \& Weaver, K. M. (2002). The moderating effect of national culture on the relationship between entrepreneurial orientation and strategic alliance portfolio extensiveness. Entrepreneurship Theory and Practice, 26(4), 145-160.

Messersmith, J. G., \& Guthrie, J. P. (2010). High performance work systems in emergent organizations: Implications for firm performance. Human Resource Management, 49(2), 241-264.

Messersmith, J. G., \& Wales, W. J. (2013). Entrepreneurial orientation and performance in young firms: The role of human resource management. International Small Business Journal, 31(2), 115-136.

Miles, R. E., Snow, C. C., Meyer, A. D., \& Coleman, H. J. (1978). Organizational strategy, structure, and process. The Academy of Management Review, 3(3), 546.

Miller, D., \& Friesen, P. H. (1982). Innovation in conservative and entrepreneurial firms: Two models of strategic momentum. Strategic Management Journal, 3(1), 1-25.

Miller, K. D. (2007). Risk and rationality in entrepreneurial processes. Strategic Entrepreneurship Journal, 1(1-2), 57-74.

Morris, M. H., Schindehutte, M., \& Laforge, R. W. (2002). Entrepreneurial marketing: A construct for integrating emerging entrepreneurship and marketing perspectives. Journal of Marketing Theory and Practice, 10(4), 1-19.

Nonaka, I. (1994). A dynamic theory of organizational knowledge creation. Organization Science, 5(1), 14-37.

Pak, J., \& Kim, S. (2016). Team managers' implementation, high performance work systems intensity, and performance: A multilevel investigation. Journal of Management, 0149206316646829.

Pearce, J. A. I., Fritz, D. A., \& Davis, P. S. (2010). Entrepreneurial orientation and the performance of religious congregations as predicted by rational choice theory. Entrepreneurship Theory and Practice, 34, 219-248.

Pfeffer, J. (1996). When it comes to "best practices" - Why do smart organizations occasionally do dumb things? Organizational Dynamics, 25(1), 33-44.

Pfeffer, J. (1998). The human equation: Building profits by putting people first. Harvard Business Press.

Podsakoff, P. M., Mackenzie, S. B., Lee, J. Y., \& Podsakoff, N. P. (2003). Common method biases in behavioral research: A critical review of the literature and recommended remedies. The Journal of Applied Psychology, 88(5), 879-903.

Posthuma, R. A., Campion, M. C., Masimova, M., \& Campion, M. A. (2013). A high performance work practices taxonomy integrating the literature and directing future research. Journal of Management, 39(5), 1184-1220.

Prieto, I. M., \& Santana, M. P. P. (2012). Building ambidexterity: The role of human resource practices in the performance of firms from Spain. Human Resource Management, 51(2), 189-211.

Rauch, A., Wiklund, J., Lumpkin, G. T., \& Frese, M. (2009). Entrepreneurial orientation and business performance: An assessment of past research and suggestions for the future. Entrepreneurship Theory and Practice, 33(3), 761-787.

Runyan, R., Droge, C., \& Swinney, J. (2008). Entrepreneurial orientation versus small business orientation: What are their relationships to firm performance? Journal of Small Business Management, 46(4), 567-588. 
Sanzo, M. J., Santos, M. L., Garcia, N., \& Trespalacios, J. A. (2012). Trust as a moderator of the relationship between organizational learning and marketing capabilities: Evidence from Spanish SMEs. International Small Business Journal, 30(6), 700-726.

Schmelter, R., Mauer, R., Börsch, C., \& Brettel, M. (2010). Boosting corporate entrepreneurship through HRM practices: Evidence from German SMEs. Human Resource Management, 49(4), 715-741.

Schuler, R. S. (1986). Fostering and facilitating entrepreneurship in organizations: Implications for organization structure and human resource management practices. Human Resource Management, 25(4), 607-629.

Senge, P. M. (1990). The fifth discipline. Measuring Business Excellence, 1(3), 46-51.

Shi, Y., \& Li, N. (2011). Research on high performance human resource practice: Theoretical review, analysis and future. Journal of Management Review, 23(10), 83-90.

Shin, D., \& Konrad, A. M. (2017). Causality between high-performance work systems and organizational performance. Journal of Management, 43(4), 973-997.

Snell, S., \& Bohlander, G. W. (2010). Principles of human resource management. South-Western Cengage Learning.

Stam, W., \& Elfring, T. (2015). Entrepreneurial orientation and new venture performance: The moderating role of intraand extra-industry social capital. The Academy of Management Journal, 51(1), 97-111.

Su, Z. X. (2010). High performance human resource management system of Chinese enterprises in transitional period: An empirical study of localization. Nankai Business Review, 13(4), 99-108.

Sun, L. Y., Aryee, S., \& Law, K. S. (2007). High-performance human resource practices, citizenship behavior, and organizational performance: A relational perspective. The Academy of Management Journal, 50(3), 558-577.

Takeuchi, R., Lepak, D. P., Wang, H., \& Takeuchi, K. (2007). An empirical examination of the mechanisms mediating between high-performance work systems and the performance of Japanese organizations. The Journal of Applied Psychology, 92(4), 1069

Tang, J., Tang, Z., Marino, L. D., Zhang, Y., \& Li, Q. (2008). Exploring an inverted u-shape relationship between entrepreneurial orientation and performance in Chinese ventures. Entrepreneurship Theory and Practice, 32(1), 219-239.

Thanos, I. C., Dimitratos, P., \& Sapouna, P. (2016). The implications of international entrepreneurial orientation, politicization and hostility upon SME international performance. International Small Business Journal, 0266242616641749

Wales, W. J., Patel, P. C., Parida, V., \& Kreiser, P. M. (2013). Nonlinear effects of entrepreneurial orientation on small firm performance: The moderating role of resource orchestration capabilities. Strategic Entrepreneurship Journal, 7(2), 93-121.

Walter, A., Auer, M., \& Ritter, T. (2006). The impact of network capabilities and entrepreneurial orientation on university spin-off performance. Journal of Business Venturing, 21(4), 541-567.

Wang, C. L. (2008). Entrepreneurial orientation, learning orientation, and firm performance. Entrepreneurship Theory and Practice, 32(4), 635-656.

Wang, K. Y., Hermens, A., Huang, K. P., \& Chelliah, J. (2015). Entrepreneurial orientation and organizational learning on SMEs' innovation. International Journal of Organizational Innovation.

Way, S. A., \& Johnson, D. E. (2005). Theorizing about the impact of strategic human resource management. Human Resource Management Review, 15(1), 1-19.

Wei, L. Q., \& Lau, C. M. (2010). High performance work systems and performance: The role of adaptive capability. Human Relations, 63(10), 1487-1511.

Wiersema, M. F., \& Bantel, K. A. (1992). Top management team demography and corporate strategic change. The Academy of Management Journal, 35(1), 91-121.

Wiklund, J. (1999). The sustainability of the entrepreneurial orientation-performance relationship. Entrepreneurship Theory and Practice, 24(1), 37-48.

Wiklund, J., \& Shepherd, D. (2003). Knowledge-based resources, entrepreneurial orientation, and the performance of small and medium-sized businesses. Strategic Management Journal, 24(13), 1307-1314.

Wiklund, J., \& Shepherd, D. (2005). Entrepreneurial orientation and small business performance: A configurational approach. Journal of Business Venturing, 20(1), 71-91.

Xiao, Z., \& Björkman, I. (2006). High commitment work systems in Chinese organizations: A preliminary measure. Management and Organization Review, 2(3), 403-422.

Youndt, M. A., Snell, S. A., Dean, J. W., \& Lepak, D. P. (1996). Human resource management, manufacturing strategy, and firm performance. The Academy of Management Journal, 39(4), 836-866.

Zahra, S. A., \& Covin, J. G. (2015). Contextual influences on the corporate entrepreneurship - performance relationship: A longitudinal analysis. Entrepreneurship Research Journal, 10(1), 43-58.

Zhang, H. Y., Li, R. F., \& Yao, Q. (2012). A meta-analysis between high performance system and corporate performance in Chinese context. Nankai Bus Rev, 15(3), 139-149.

Zhu, C. L., \& Chen, X. L. (2014). High performance work systems and employee creativity: The mediating effect of knowledge sharing. Frontiers of Business Research in China, 8(3), 367-387. 